\title{
An Implementation of Outpatient Online Registration Information System of Mutiara Bunda Hospital
}

\author{
Masniah \\ College of Informatics and Computer Management \\ STMIK Banjarbaru \\ Banjarbaru, Indonesia
}

\begin{abstract}
Outpatient care is one of the medical services in Mutiara Bunda hospital. The management of outpatient registration of Mutiara Bunda Hospital used conventional way. Within 1 hour serving, 5 patients were enrolled with an average time of 13 minutes per patient. This caused the registration queue to get outpatient services. The study was conducted with the aim to produce outpatient online registration information system design of Mutiara Bunda Hospital in order to increase outpatient registration service and to manage data in getting medical care.

The patients register on Outpatient Online Registration Information System without having to come first to the hospital and get a queue number, so they can estimate the waiting time in the hospital to get medical care at Mutiara Bunda Hospital; while the patients who come to the hospital are served directly by the registrar.

From the results of the research, it can be concluded that the application of Outpatient Online Registration Information System help in managing and processing data of patient registration to be able to get medical care immediately at Mutiara Bunda Hospital.
\end{abstract} System

Keywords-Online Registration; Outpatient; Information

\section{INTRODUCTION}

Mutiara Bunda Hospital is a private hospital which provides medical services to the community including a Home Care Unit, Emergency Room (ER), Inpatient, Outpatient, Clinical Laboratory, Pharmacy, and Medical Check Up. In 2015, the outpatient service consists of four polyclinics: General polyclinic has 8 doctors, Obstetrics and Gynecology polyclinic has 3 doctors, Medical and Aesthetic Acupuncture polyclinic has one doctor and Psychology polyclinic has 2 doctors.

In managing outpatient registration, Mutiara Bunda Hospital used conventional way in which patients came directly and patient data is recorded on a sheet of paper. This caused the registration queue in getting outpatient medical care.

The study was conducted with the aim to produce outpatient online registration information system design in Mutiara Bunda Hospital in order to increase outpatient registration service and to manage data in getting medical care.

\section{THEORITICAL BASIS}

A system is a network of interconnected procedures, cohere to perform an activity or to accomplish a particular goal (Jogiyanto HM, 2009).

An information system is a man-made system which provides an integrated set of manual components and computerized components in order to collect data, process data, and generate information for users (Sidarta, 1995).

A patient is a person who consults health problems to obtain the necessary health services either directly or indirectly to the doctor or dentist. Hospital Management Information System or HMIS is a communication information technology system which processes and integrates the entire workflow process of Hospital services in the form of coordination network, reporting and administrative procedures for obtaining information appropriately and accurately; and is part of the Health Information System (Permenkes No: 269, 2008).

Outpatient is a patient care for observation, diagnosis, treatment, medical rehabilitation and other health services without staying in the hospital (Menkes No: 560, 2003).

A good service quality must be provided by a service business. With the rise of new competitors will lead to intense competition in obtaining consumers as well as retaining customers. The observant consumers will naturally choose the good quality goods and services (Nova, 2010).

Hospital as a public service institution requires the existence of an information system which is accurate and reliable, and sufficient to improve services to patients as well as other relevant environment. With such a broad scope of services, of course, there are many complex problems which occur in the process of hospital services. The numbers of variables in the hospital determine the speed of the information flow needed by the users and the hospital environment (Handoyo etc, 2008).

According to Lidia Andriani (2009) in her research entitled Outpatient Registration Information System in Hospital by Using a Computer Program, by using Outpatient Registration Information System, the registration process of outpatients can be done easily and quickly; avoids double medical record numbers because this system can detect if there is any identical 
medical record numbers; facilitates registrar in printing medical cards, patients' identity and patient visit; provides information of daily and monthly reports quickly and the type of report may vary according to the needs; and saves time and energy of the patient registrars.

Dwi Parawanto (2012), in his research entitled Patient Administration and Registration Information Systems in SADEWA Mother and Child Hospital, generated Patient Administration and Registration Information Systems which processes data of patients, doctors, employees, examinations and administrations. The data then was considered as references for decision making by the doctors or the hospital, thus the services to patients would be improved.

According to Gunawan Susanto and Sukadi (2012), in their journal entitled Medical Record Information Systems On Regional Public Hospital (RPH) of Pacitan Web-Base Based, by developing a web-based medical record information system in RPH of Pacitan double medical records can be reduced and searching of medical record status can be done quickly, this overcame the medical record keeping system which has been used previously. The previous system stored the patients' medical records locally where the patients were examined and treated, this did not allow the direct data exchanging. This medical record information system helps medical personnel to carry out health services to patients.

Bambang Eka Purnama and Sri Hartati (2012), in their journal entitled Conveniences and Benefits of Patient Medical Database and Elasticity for Therapy Accessibility in Different Locations, explained that the Medical Record Information System which has been developed based on the standard among hospitals and clinics provides the benefits of conveniences and records of patient's medical history so that the number misdiagnosis and malpractices can be pressed.

Ahmad Anshari and Bambang E P (2013), in their journal entitled Distributed Data Patient In Medical Record Information System, with the Information system will be able to overcome the problem of data search quickly at a hospital. Patients who visit any hospital will feel comfortable and Mall practice would be suppressed because can easily find previous patient history data, so as to determine the subsequent diagnosis becomes easier.

\section{SYSTEM ANALYSIS AND DESIGN}

\section{A. Problem Analysis}

In the system of patient registration processing at Mutiara Bunda Hospital, there were several constraints in the processing and reporting of patient registration data. Based on interviews with registrar, revealed that the records of outpatients data used conventional way in which the data was written on sheets of paper in a large book. The number of patients in a doctor's practice schedule has been determined. Searching in the book caused the patients who came directly did not get queued at their desire. The long queues of patients caused the requirement of an online information system so the registration process will be faster and more efficient

\section{B. System Design}

a) Context Diagram

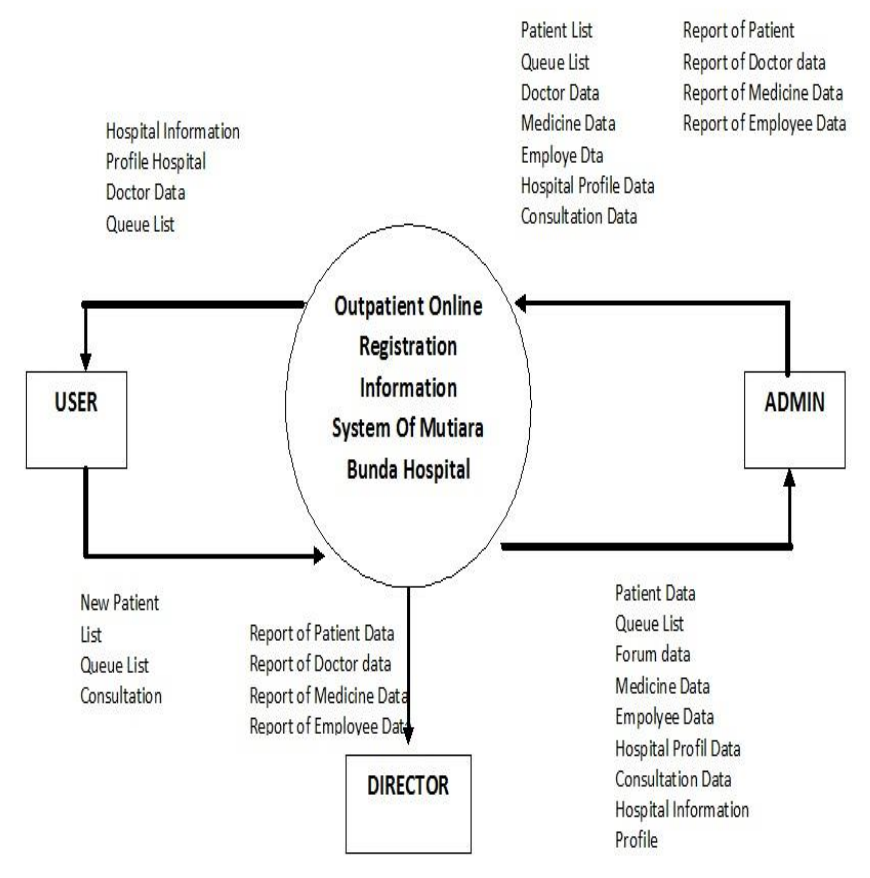

Fig. 1. Context Diagram

\section{b) Use Case Diagram}

Use Case diagram illustrates the common features of the Outpatient Online Registration Information System of Mutiara Bunda Hospital. To get into the system, the user must log in first.

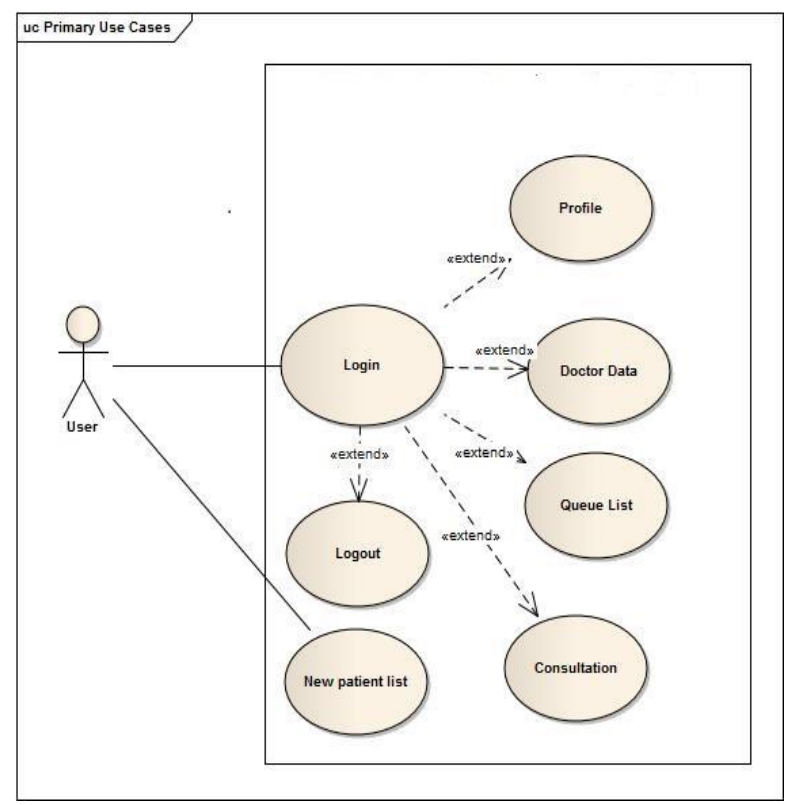

Fig. 2. Use Case of User 


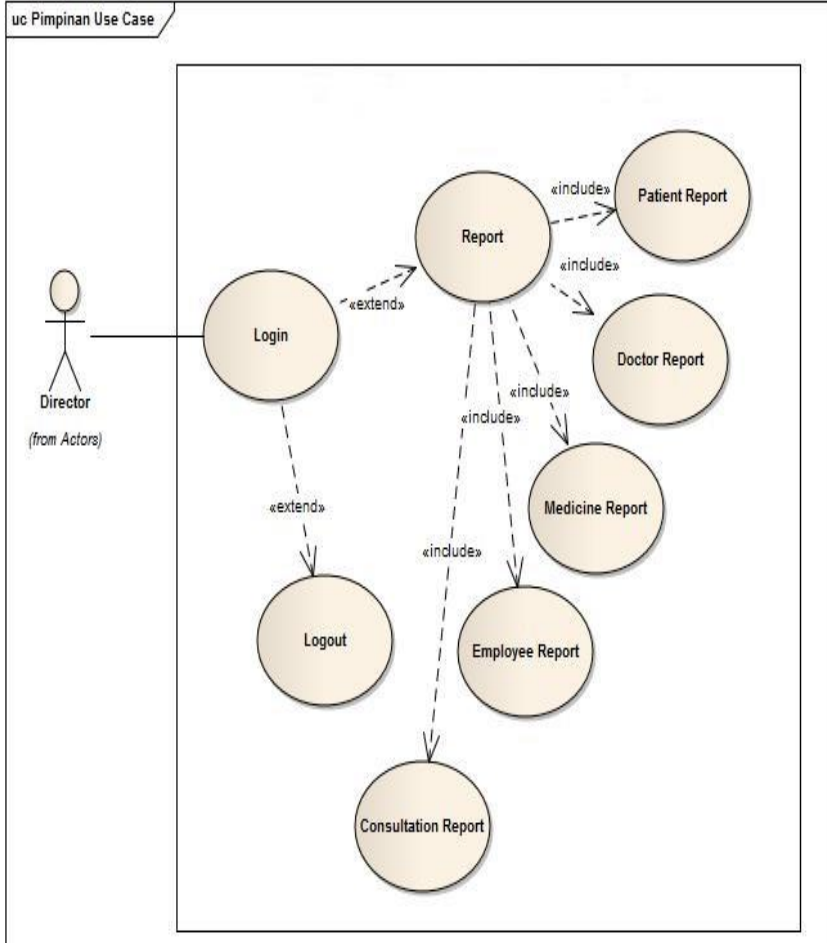

Fig. 3. Use Case of Director

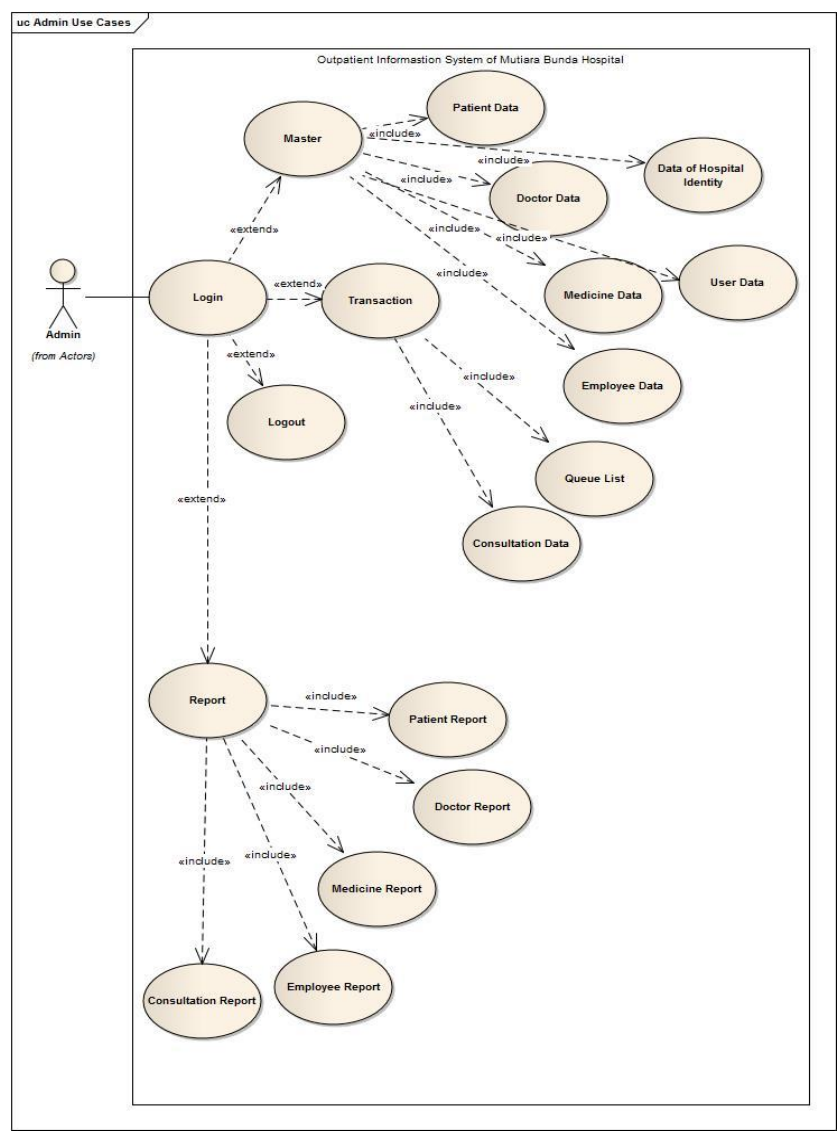

Fig. 4. Use Case of Admin c) Activity Diagram

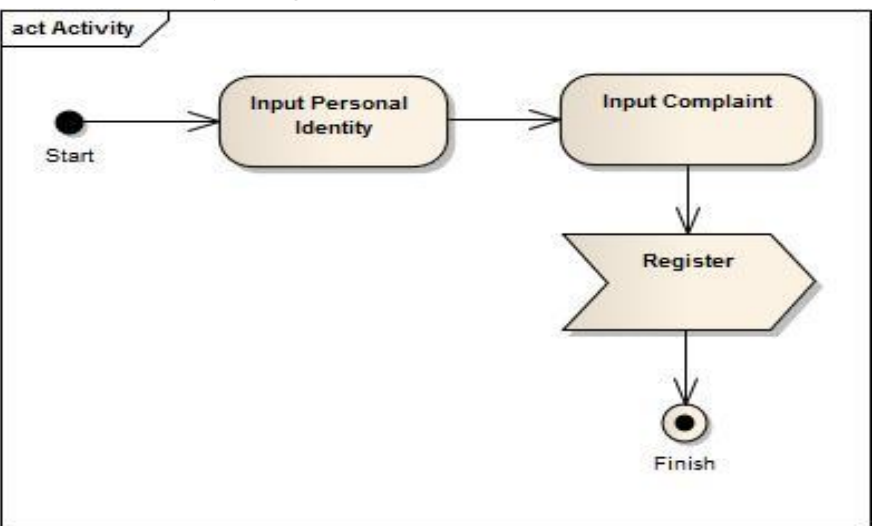

Fig. 5. Diagram Activity of Queue List

Fig 5. Activity diagram of queue list describes the process when the user enrolls for registration queue to get treatment or consultation with a doctor in Mutiara Bunda hospital.

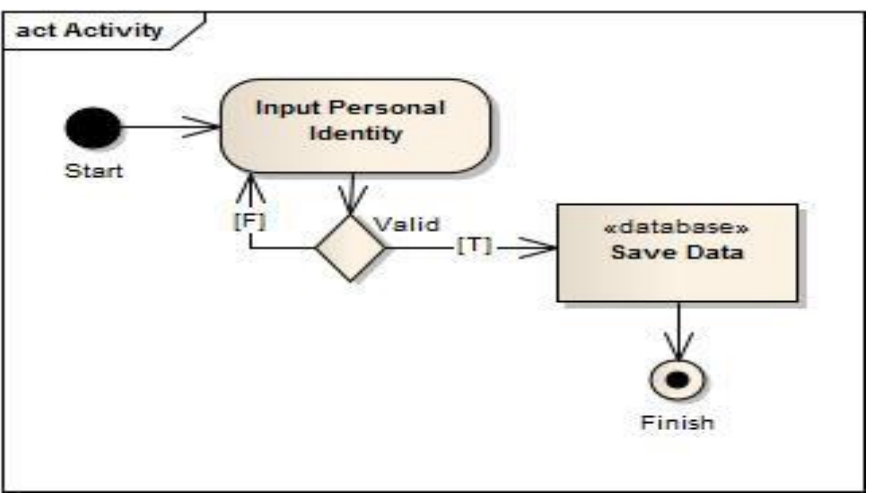

Fig. 6. Diagram Activity New of Patient List

Fig 6. Activity diagram of patient list illustrates the process of registering as new patients on Web page of Outpatient Online Registration Information System of Mutiara Bunda Hospital.

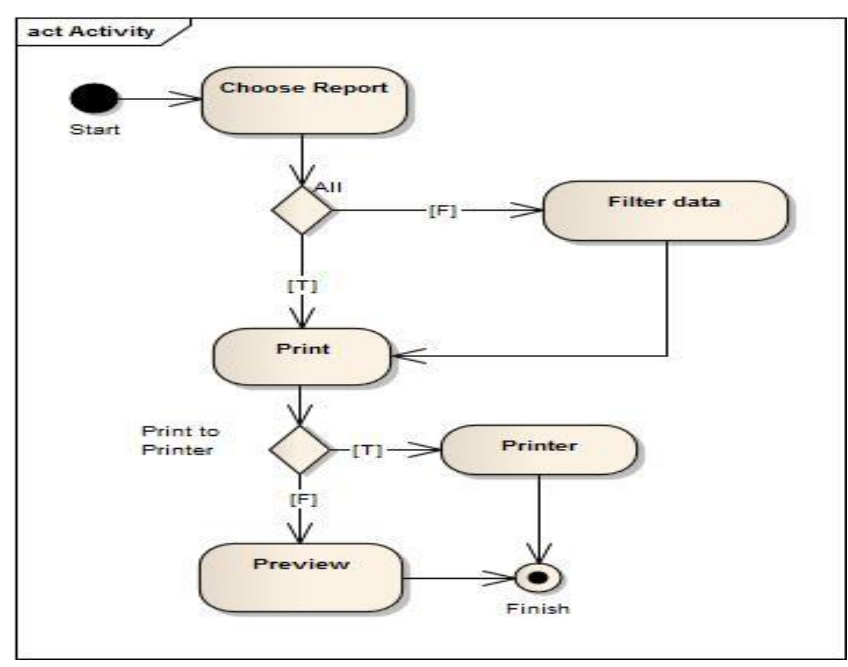

Fig. 7. Diagram Activity of Report 
Fig 7. Activity diagram of report describes the activity processes of making a report to printing the report.

d) Sequence Diagram

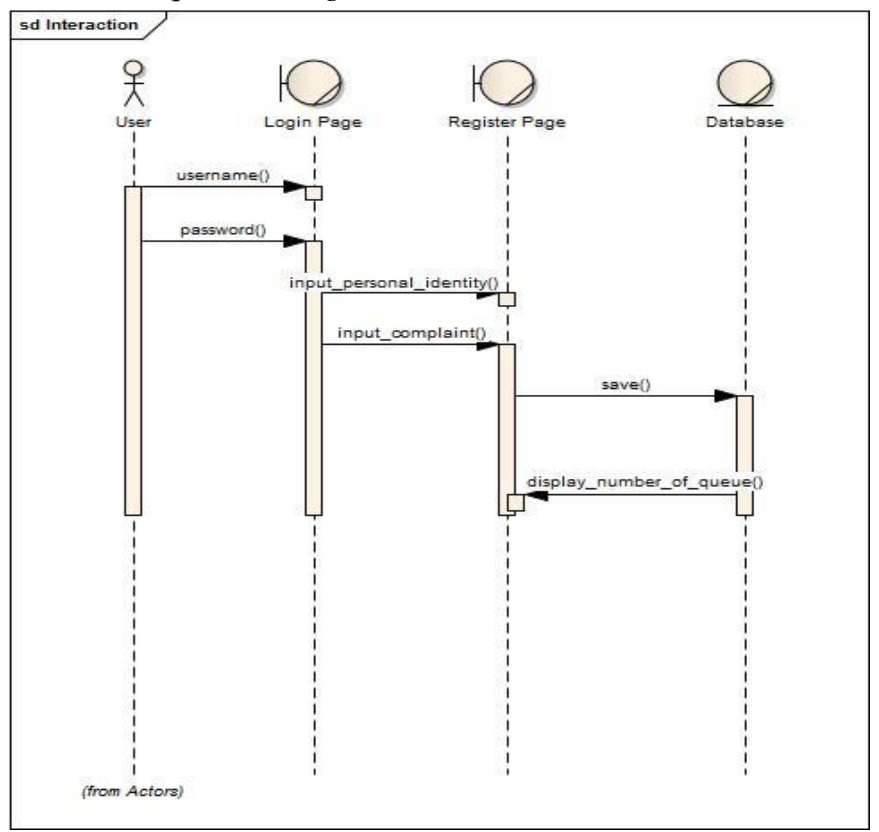

Fig. 8. Sequence Diagram of Queue List

Fig 8. Sequence Diagram of Queue list describe the process when the user enrolls for registration queue to get treatment or consultation with a doctor in Mutiara Bunda hospital.

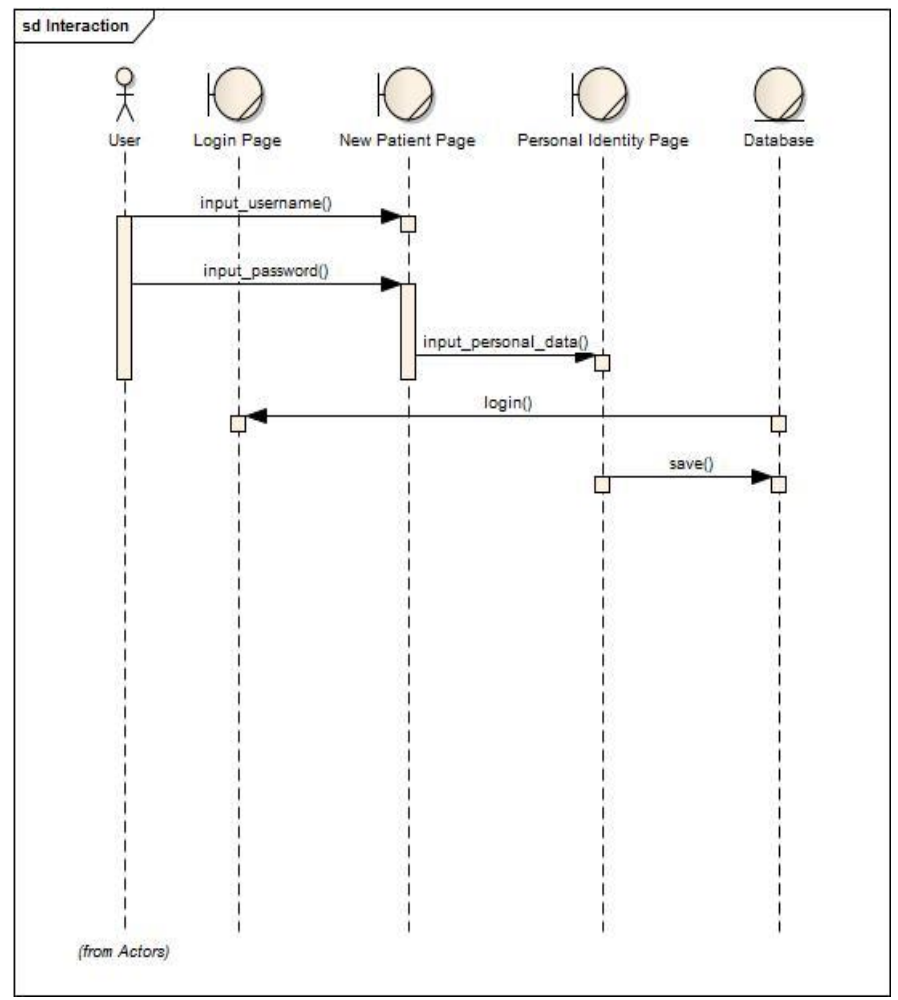

Fig. 9. Sequence Diagram of Patient List
Fig 9.Sequence diagram of Patient List illustrate the process of registering as a new patient on Outpatient Online Registration Information System Web page of Mutiara Bunda Hospital.

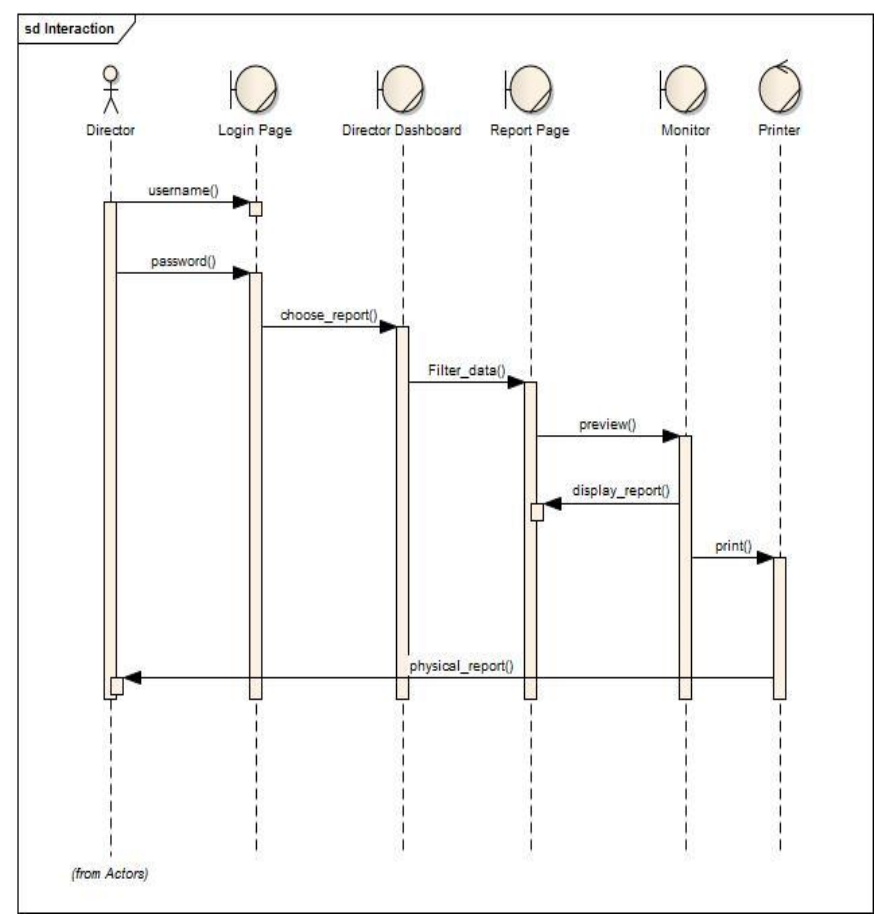

Fig. 10. Sequence Diagram of Report

Fig 10. Sequence Diagram of Report describes the activity processes of making to printing a report.

e) Database Model

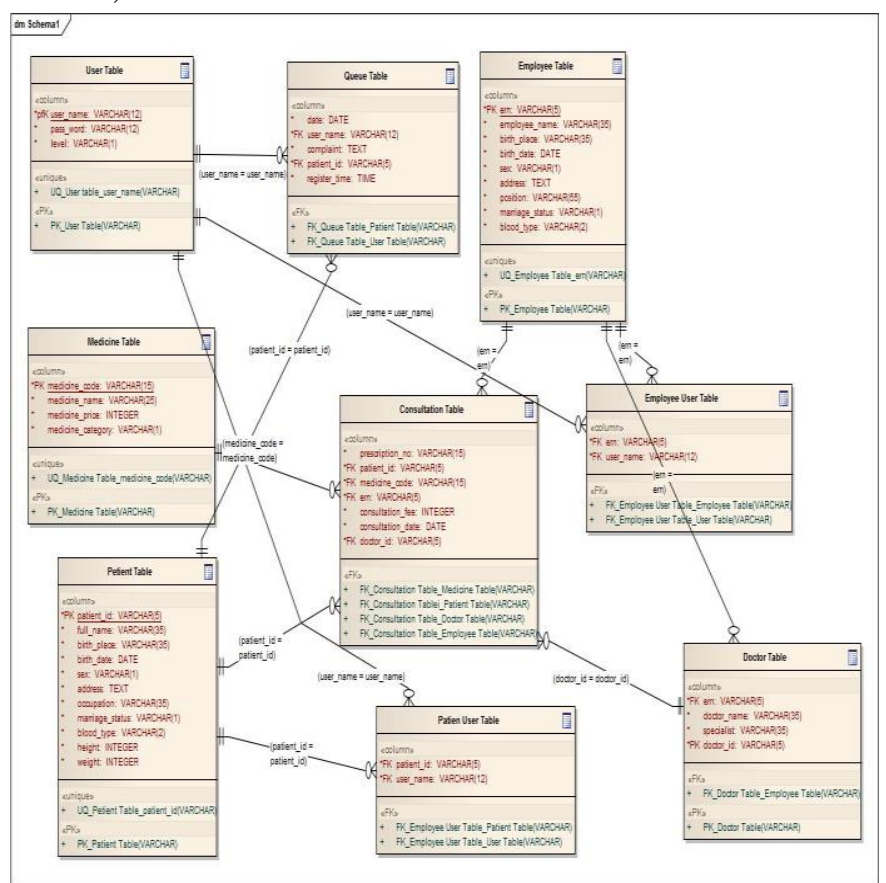

Fig. 11. Database Model 


\section{f) Database Design}

TABLE I. TABLE USER

\begin{tabular}{|l|l|l|}
\hline Field Name & Type & Information \\
\hline user_name & varchar(12) & PRIMARY \\
\hline pass_word & varchar(12) & - \\
\hline Level & varchar(1) & Director, user \& admin \\
\hline
\end{tabular}

TABLE II. TABLE QUeUE

\begin{tabular}{|l|l|l|}
\hline Field Name & Type & Information \\
\hline Date & Date & - \\
\hline user_name & varchar(12) & FOREIGN \\
\hline Complaint & Text & - \\
\hline patient_id & varchar(5) & - \\
\hline register_time & Time & - \\
\hline
\end{tabular}

TABLE III. TABLE EMPLOYEE

\begin{tabular}{|l|l|l|}
\hline Field Name & Type & Information \\
\hline ERN & varchar(5) & PRIMARY \\
\hline employee_name & varchar(35) & - \\
\hline birth_place & varchar(35) & - \\
\hline birth_date & Date & - \\
\hline sex & varchar(1) & - \\
\hline address & Text & - \\
\hline position & varchar(55) & - \\
\hline marriage_status & varchar(1) & - \\
\hline blood_type & varchar(2) & - \\
\hline
\end{tabular}

TABLE IV. TABLE MEDICINE

\begin{tabular}{|l|l|l|}
\hline Field Name & Type & Information \\
\hline medicine_code & varchar(15) & PRIMARY \\
\hline medicine_name & varchar(25) & - \\
\hline medicine_price & int(11) & - \\
\hline $\begin{array}{c}\text { medicine_categ } \\
\text { ory }\end{array}$ & $\operatorname{varchar}(1)$ & - \\
\hline
\end{tabular}

TABLE V. TABLE DOCTOR

\begin{tabular}{|l|l|l|}
\hline Field Name & Type & Information \\
\hline ERN & $\operatorname{varchar}(5)$ & FOREIGN \\
\hline doctor_name & $\operatorname{varchar}(35)$ & Name \\
\hline Specialist & $\operatorname{varchar(35)}$ & - \\
\hline doctor_id & $\operatorname{varchar(5)}$ & PRIMARY \\
\hline
\end{tabular}

TABLE VI. CONSULTATION

\begin{tabular}{|l|l|l|}
\hline Field Name & Type & Information \\
\hline prescription_no & varchar(15) & - \\
\hline patient_id & $\operatorname{varchar}(5)$ & FOREIGN \\
\hline medicine_code & $\operatorname{varchar}(15)$ & FOREIGN \\
\hline ERN & $\operatorname{varchar(5)}$ & FOREIGN \\
\hline consultation_fee & int(11) & - \\
\hline consultation_date & Date & - \\
\hline doctor_id & varchar(5) & FOREIGN \\
\hline
\end{tabular}

TABLE VII. PATIENT USER

\begin{tabular}{|l|l|l|}
\hline Field Name & Type & Information \\
\hline patient_id & varchar(5) & FOREIGN \\
\hline user_name & varchar(12) & FOREIGN \\
\hline
\end{tabular}

TABLE VIII. PATIENT

\begin{tabular}{|l|l|l|}
\hline Field Name & Type & Information \\
\hline patient_id & varchar(5) & PRIMARY \\
\hline full_name & varchar(35) & - \\
\hline birth_place & varchar(35) & - \\
\hline birth_date & Date & - \\
\hline Sex & varchar(1) & - \\
\hline Address & Text & - \\
\hline occupation & varchar(55) & - \\
\hline marriage_status & varchar(1) & - \\
\hline blood_type & varchar(2) & - \\
\hline Height & int(11) & - \\
\hline Weight & int(11) & - \\
\hline
\end{tabular}

TABLE IX. TABLE EMPLOYEE USER

\begin{tabular}{|l|l|l|}
\hline Field Name & Type & Information \\
\hline ERN & varchar(5) & FOREIGN \\
\hline user_name & $\operatorname{varchar}(12)$ & FOREIGN \\
\hline
\end{tabular}

TABLE X. IDENTITY HOSPITAL

\begin{tabular}{|l|l|l|}
\hline Field Name & Type & Information \\
\hline hospital_name & varchar(35) & Hospital Name \\
\hline phone_no. & varchar(15) & Phone Number \\
\hline E-mail & varchar(35) & - \\
\hline Address & Text & - \\
\hline Owner & varchar(35) & - \\
\hline license_no. & varchar(35) & Number of Licensing \\
\hline Website & varchar(35) & Hospital Website \\
\hline
\end{tabular}

\section{g) Interface Design}

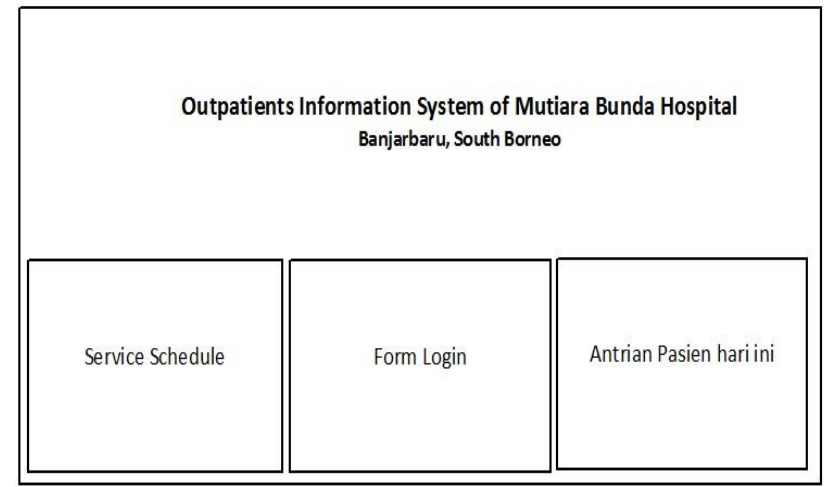

Fig. 12. Home Page

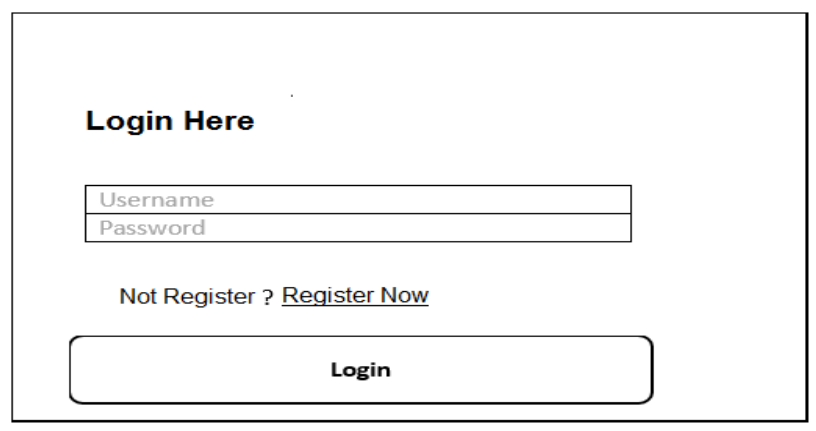

Fig. 13. Login Form 


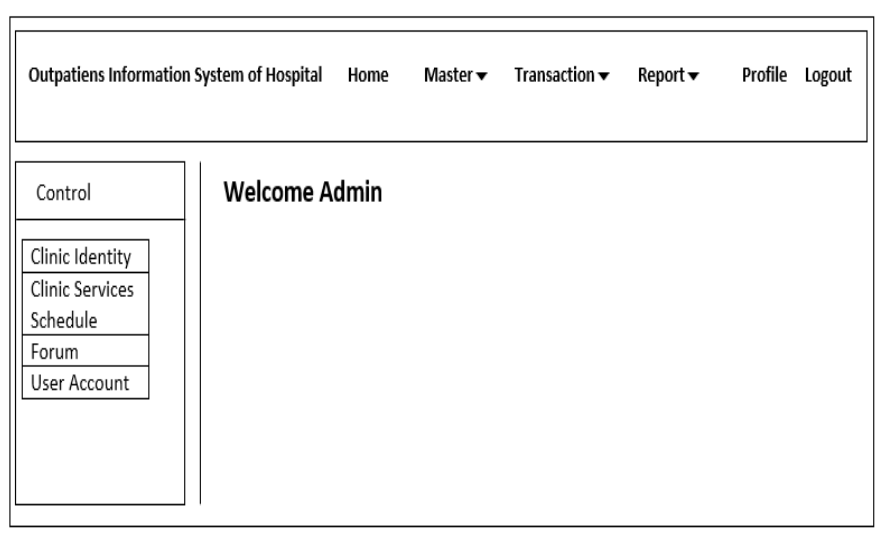

Fig. 14. Admin Dashboard

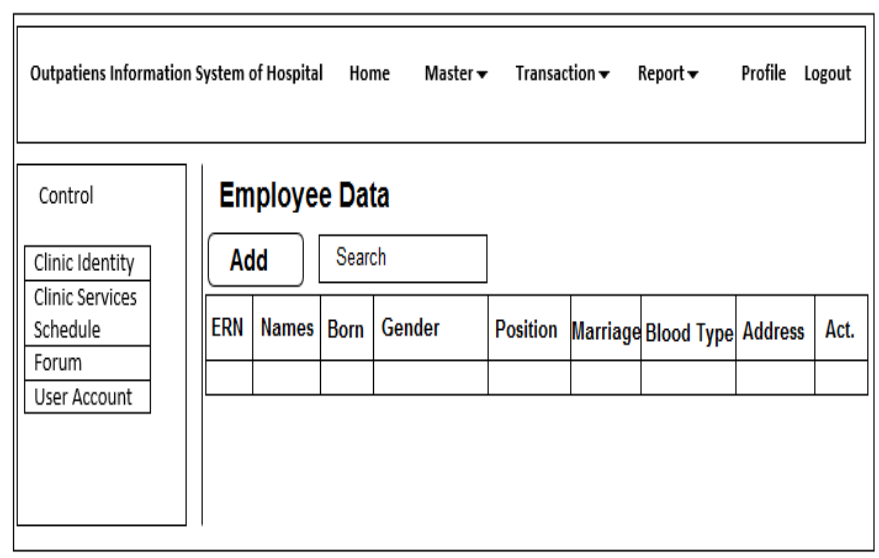

Fig. 15. Employee Dashboard

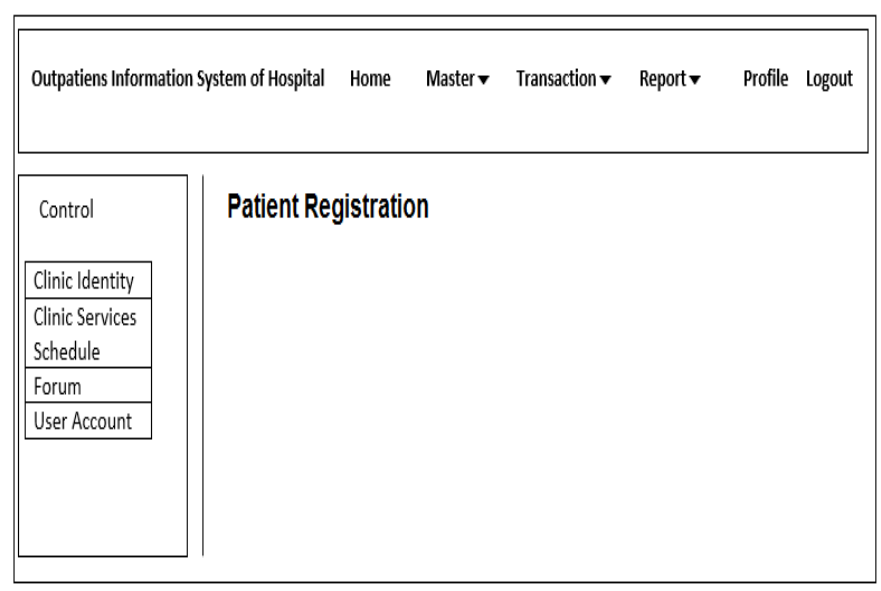

Fig. 16. Patient Registration Dashboard

\section{IMPLEMENTATION OF THE SYSTEMS}

\section{A. The Users of Outpatients Online Registration Information System}

The users of outpatient online registration information system are administrator who is the holder of the highest privileges in the system, doctors, staff and patients.

\section{B. Display Interface}

Outpatients Information System of Mutiara Bunda Hospital Banjarbaru, South Borneo

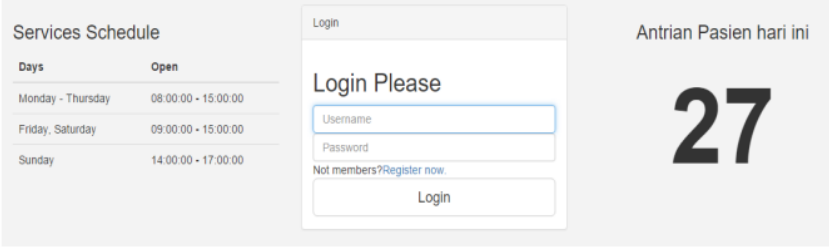

Fig. 17. Display of Homepage

Fig 17. Display of Homepage Outpatients Online Registration Information System has a main page which contains the login form used to authenticate the user in order to access the system, a link to the registration form (register now) used for user registration, and display of the service schedule and the number of queues.

Login

\section{Login Please}

Username
Password
Not members?Register now.
Login

Fig. 18. Display of Form Login

Fig 18. Display the Login Form, user must enter a user name and password in order to access the Outpatients Online Registration Information System. If the user is a patient, then the user who has not been registered can register an account by clicking "Register now".

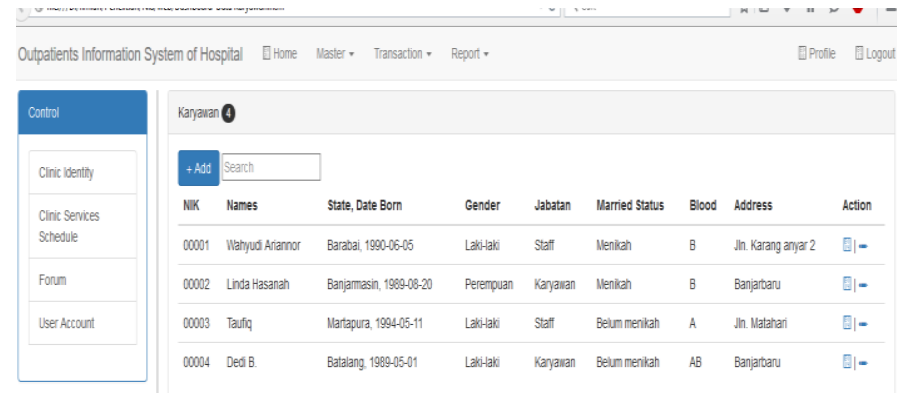

Fig. 19. Display of the Employee Data Page

Fig 19. Display the Employee Data Page, the user can control the data by adding, changing, or deleting the data of employees. 


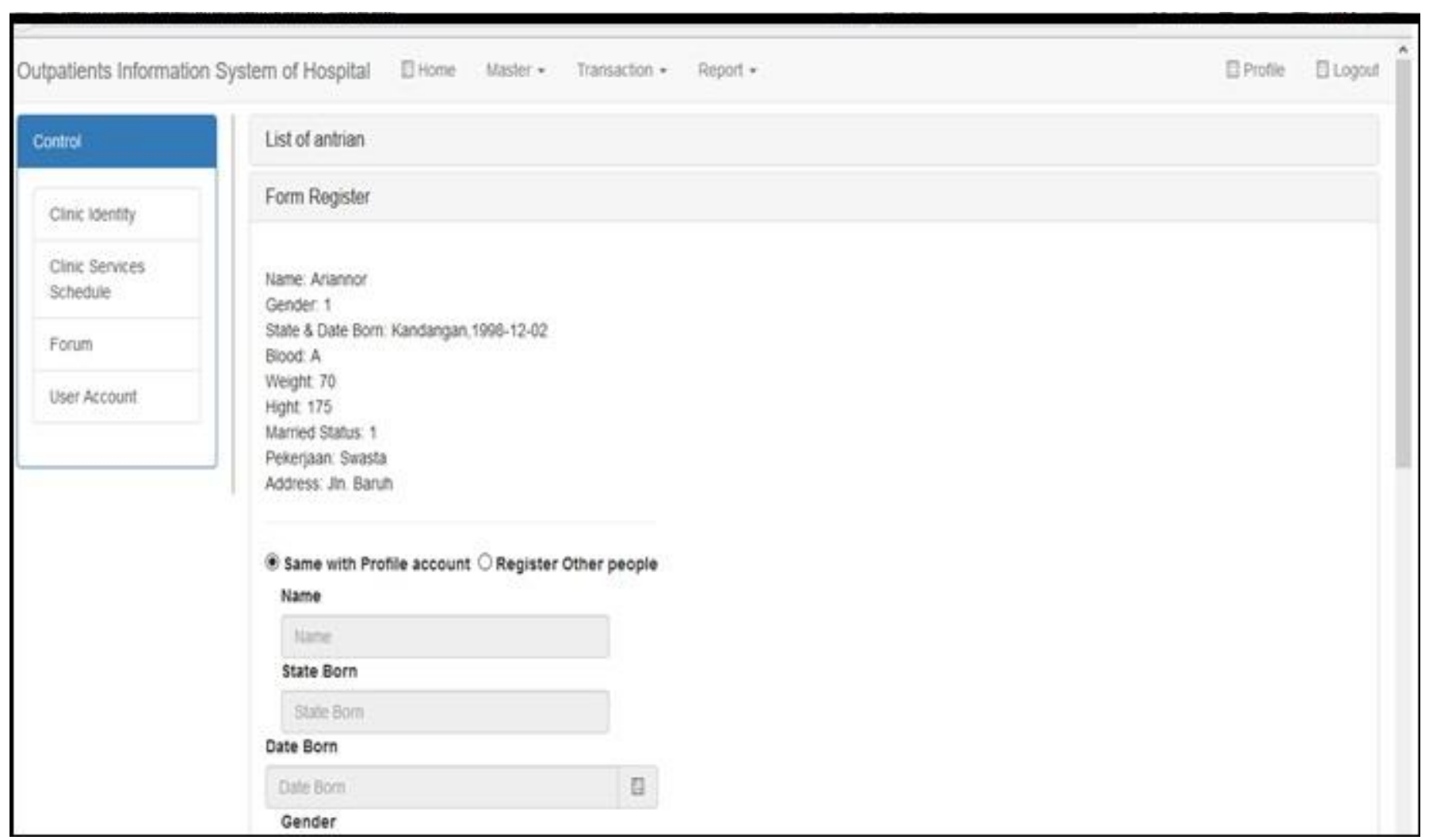

Fig. 20. Display of Outpatients Online Registration

Fig 20. Display of outpatients online registration, the patients who have filled the form on Outpatients Online Registration Information System will get queue numbers which can be be printed.

\section{CONCLUSION}

From the results of research, it can be concluded that:

1) The average time of outpatient registration in Mutiara Bunda Hospital conventionally per patient was 13 minutes which includes acceptance of patients, recording the patient's identity, storing data, and taking medical records of patients. Within 1 hour, only about 5 patients registration can be served.

2) On the Outpatients Online Registration System, the patients can register online without having to come to the hospital first, and they get queue numbers so they can estimate waiting time in the hospital to get medical care from Mutiara Bunda Hospital. While the patients who come directly to the hospital will received by the registrar.

3) After applying the Outpatient Online Registration Information System, number of patients served in 1 hour is approximately 12 patients. This means the application of Outpatient Online Registration Information System help to manage and process of patient registration data to be able to get medical care at Mutiara Bunda Hospital immediately.

\section{REFERENCES}

[1] Jogiyanto, HM., Perancangan Sistem Informasi Pengenalan Komputer. Yogyakarta: Pustaka Pelajar, 2009.

[2] Sidharta, Pengantar Sistem Informasi Bisnis, P.T. ELEX Media Komputindo, Jakarta, 1995.

[3] Kementerian Kesehatan Republik Indonesia. 2007. Peraturan Menteri Kesehatan Republik Indonesia Nomor 269/Menkes/Per/III/2008 Tentang Rekam Medis.

[4] Keputusan Menteri Kesehatan Republik Indonesia Nomor 560/MENKES/SK/IV/2003. 2003 Tentang Tarif Perjan Rumah Sakit.

[5] Nova, R. F. Pengaruh Kualitas Pelayanan Terhadap Kepuasan Pasien Rawat Inap Pada Rumah Sakit Pku Muhammadiyah Surakarta. Skripsi, 21, 2010.

[6] Handoyo, E., Budi Prasetijo, A., \& Noor Syamhariyanto, F. Aplikasi sistem informasi rumah sakit berbasis web pada sub-sistem farmasi menggunakan framework prado. Vol. 7 No. 1 Januari - Juni 2008, 1,2010 .

[7] Andriani, Lidya et al. Sistem Informasi Pendaftaran Pasien Rawat Jalan Di Rumah Sakit Dengan Menggunakan Program Komputer. USU Repository @ 2009.

[8] Parawanto, Dwi. Sistem Informasi Administrasi dan Pendaftaran Pasien pada Rumah Sakit Ibu dan Anak SADEWA, 2012.

[9] Susanto,Gunawan \& Sukadi. Sistem Informasi Rekam Medis Pada Rumah Sakit Umum Daerah (RSUD) Pacitan Berbasis Web Base." Speed - Sentra Penelitian Engineering dan Edukasi 9(3): 40-46, 2012.

[10] Purnama., Eka, Bambang., \& Hartati, Sri.Convenience and Medical Patient Database Benefits and Elasticity for Accessibility Therapy in Different Locations." International Journal of Advanced Computer Science and Applications 3(9): 54-60, 2012.

[11] Ana Nur Cahyanti, Bambang Eka Purnama, Pembangunan Sistem Informasi Manajemen Puskesmas Pakis Baru Nawangan, Jurnal Speed Volume 9 No 2 - Agustus 2012 , ISSN 1979 - 9330 
[12] Bambang Eka Purnama, Ahmad Ashari (2013), Distributed Data Patient In Medical Record Information System, IJSTR - International Journal Of Scientific \& Technology Research Volume 2, Issue 8, August 2013 ISSN 2277-8616

[13] Ernawati, Bambang Eka Purnama, Implementasi Sistem Informasi Puskesmas Pembantu Desa Nglaran, Jurnal IJNS Volume 3 No 3 Juli 2014, ISSN: 2302-5700 (Print) 2354-6654 (Online), ijns.apmmi.org
[14] Hendik Mulyanarko Bambang Eka Purnama Sukadi, Pembangunan Sistem Informasi Billing Pada Rumah Sakit Umum Daerah (Rsud) Kabupaten Pacitan Berbasis Web, Jurnal TIK Provisi Vol 4, No 2 Agustus 2013

[15] Bambang Eka Purnama, Ahmad Ashari, Distributed Data Patient In Medical Record Information System, International Journal Of Scientific \& Technology Research Volume 2, ISSUE 8, AUGUST 2013 ISSN 2277-8616 